\title{
Ampicillin levels in sputum, serum, and saliva
}

\author{
SHEILA M. STEWART, MARY FISHER, JOY E. YOUNG, \\ and W. LUT Z

\begin{abstract}
Departments of Bacteriology, Respiratory Diseases and Social Medicine, University of Edinburgh and Wellcome Laboratory, City Hospital, Edinburgh
\end{abstract}

The ampicillin levels in sputum, serum, and saliva from 40 patients receiving a dose of $250 \mathrm{mg}$., 26 patients receiving a dose of $500 \mathrm{mg}$., and 11 patients receiving a dose of $1 \mathrm{~g}$. were estimated. The ampicillin was given orally four times daily.

The 1-2 hour and 2-3 hour sputum levels were similar in individual patients. There was no difference in the range or mean sputum or saliva levels between specimens from patients receiving $250 \mathrm{mg}$. and $500 \mathrm{mg}$., but the levels were significantly higher after the $1 \mathrm{~g}$. dose. The mean serum level showed a small increase after $500 \mathrm{mg}$. ampicillin as compared with the $250 \mathrm{mg}$. dose and a big increase after the $1 \mathrm{~g}$. dose: only the latter difference was significant. The sputum levels were approximately 30 to 40 times lower than the corresponding serum levels. There was considerable scatter in the sputum level for any level of ampicillin in the serum: in only two of the 1-2 hour sputum specimens was there no detectable ampicillin.

There was no correlation between the sputum levels and either the body weight or the dose in milligrams per kilogram. There was no evidence that corticosteroids or diuretics affected the sputum level.

It was not possible to demonstrate any relationship between the purulence of the sputum and the level of ampicillin after doses of $250 \mathrm{mg}$. or $500 \mathrm{mg}$., but higher levels were found in the more purulent specimens after $1 \mathrm{~g}$. doses.

Previous work (Hafez, Stewart, and Burnet, 1965) showed that there was considerable variation between patients in the level of penicillin in the sputum after intramuscular injection and that the sputum levels were appreciably lower than the serum levels. May and Delves (1965) reported the serum, saliva, and sputum levels in a small group of patients with chronic bronchitis treated orally with ampicillin. They found considerable variation between patients.

The present investigation was carried out to determine the range of ampicillin sputum levels in a larger series of patients with respiratory disease after treatment with doses of $250 \mathrm{mg}$., $500 \mathrm{mg}$. or $1 \mathrm{~g}$. orally four times daily. Serum levels were also assayed since these are the levels frequently quoted when assessing the adequacy of the dosage of a drug. Saliva levels were estimated because contamination of sputum with saliva containing appreciable quantities of the drug might give falsely high sputum levels. Various factors which might affect the antibiotic levels have been analysed.

Requests for reprints : Dr. S. M. Stewart, Wellcome Laboratory, City Hospital, Greenbank Drive, Edinburgh, EH10 5SB

\section{PATIENTS INVESTIGATED}

All patients were in hospital at the time the levels were investigated. The authors were not respon- $\underset{x}{\otimes}$ sible for their admission, treatment or discharge. This sample of patients can therefore not be con- 3 . sidered a truly random sample in the statistical sense, nor indeed is this a clinical trial with patients randomly allocated to different treat-o ments. Hence the results, and in particular the statistical analysis, must be interpreted witho caution. Nevertheless since we think that the ampicillin levels reached are not strongly related 0 to the criteria determining treatment, we feel the N analysis to be helpful in giving some indication $N$ of possible patient response to oral ampicillin.

\section{AMPICILLIN THERAPY}

$250 \mathrm{mg}$. Dose Forty patients received $250 \mathrm{mg} .+$ ampicillin four times daily. Twenty-five were men $\overrightarrow{0}$ and 15 women. Their ages ranged from 22 to 85 years with a mean age of $60 \cdot 6$ years.

$500 \mathrm{mg}$. Dose Twenty-six patients received 
$500 \mathrm{mg}$. ampicillin four times daily. Twenty were men and six women. Their ages ranged from 33 to 81 years with a mean age of 61.0 years.

$1 \mathrm{~g}$. Dose Eleven patients received $1 \mathrm{~g}$. ampicillin four times daily. Nine were men and two women. Their ages ranged from 60 to 76 years, the average being 67.3 years, significantly older than in the 250 and $500 \mathrm{mg}$. dose groups.

REPEATED ASSAYS These were carried out on 20 patients. In 15 instances the repeated assays were done on the same dose only. In three cases repeated assays were done both on the same dose and on a higher dose, and in two cases only on different doses (see details in Table VI). Where repeated assays were done on the same dose, only the first set of readings was used for the main analysis.

CliniCal Diagnosis The clinical diagnosis on discharge from hospital is shown in Table $I$. Forty-two of the patients with bronchitis had exacerbations of chronic bronchitis, one had acute bronchitis, and six had chronic bronchitis without an exacerbation. Four of the five patients with asthma also had evidence of an infection.

\section{T A B L E I}

CLINICAL DIAGNOSIS ON DISCHARGE IN PATIENTS INVESTIGATED

\begin{tabular}{|c|c|c|c|c|c|c|}
\hline \multirow{2}{*}{\multicolumn{4}{|c|}{ Clinical Diagnosis }} & \multicolumn{3}{|c|}{ Dose of Ampicillin q.i.d. } \\
\hline & & & & \multirow{2}{*}{$\begin{array}{c}250 \mathrm{mg} . \\
25 \\
7 \\
3 \\
4 \\
1\end{array}$} & \multirow{2}{*}{$\begin{array}{c}500 \mathrm{mg} . \\
16 \\
3 \\
5 \\
1 \\
0\end{array}$} & \multirow{2}{*}{$\begin{array}{l}1 \mathrm{~g} . \\
8 \\
1 \\
2 \\
0 \\
0\end{array}$} \\
\hline $\begin{array}{l}\text { Bronchitis } \\
\text { Pneumonia } \\
\text { Bronchiectasis } \\
\text { Asthma . } \\
\text { Cavitated bron } \\
\text { Pulmonary infa } \\
\text { secondary inf }\end{array}$ & $\begin{array}{l}\cdots \\
\cdots \\
\cdots \\
\text { chial } \\
\text { rction } \\
\text { ection }\end{array}$ & $\begin{array}{l}\cdots \\
\cdots \\
\cdots \\
\text { carcino } \\
\text { with } \\
\ldots\end{array}$ & $\begin{array}{l}\cdots \\
\cdots \\
\dot{m a} \\
\ldots\end{array}$ & & & \\
\hline Total No. of pa & tients & $\cdots$ & $\cdots$ & 40 & 26 & 11 \\
\hline
\end{tabular}

EXCLUSIONS Fourteen further patients were examined but were excluded from the main analysis. Twelve of these patients $(4$ in the $250 \mathrm{mg}$. group, 2 in the $500 \mathrm{mg}$. group, and 6 in the $1 \mathrm{~g}$. group) were excluded because the antibiotic level in the saliva was the same as or higher than the sputum level. In these cases an apparent sputum antibiotic level could have been due to contamination of the sputum with antibiotic-containing saliva. These 12 cases were included in the analysis of the saliva levels. The remaining two cases were excluded from all analyses because they had clinical renal insufficiency that might have affected the drug levels (Höffler, Stegemann, and Scheler, 1966).

\section{METHODS}

AMPICILLIN THERAPY The dose of ampicillin was decided by the clinician in charge. All patients had been receiving ampicillin for at least 18 hours before the assay dose. In order to ensure the exact timing and dosage of the drug, the 6 a.m. dose on the day of assay was omitted, and the last dose was given at 10 p.m. the previous evening. The assay dose was given by one of us (M. F.) at approximately 9 a.m. No antibacterial drugs other than ampicillin were given. The second dose of ampicillin on the day of assay was withheld until the last specimens for assay had been collected.

In calculating the duration of therapy the first day has been considered as day 1 . Only treatment with ampicillin in hospital has been taken into account as the details of other therapy were often not available.

MEALTIMES No attempt was made to regulate or to record the food ingested by the patients. They had breakfast between 7.45 and 8.00 a.m. and coffee or tea (sometimes with biscuits, etc.) at about 10.30 a.m. The final specimens of sputum were invariably collected before lunch was served.

CORTICOSTEROIDS AND DIURETICS Ten of the patients on the $250 \mathrm{mg}$. dose, six of those receiving $500 \mathrm{mg}$., and three of those on the $1 \mathrm{~g}$. dose were also receiving prednisolone, 5 to $50 \mathrm{mg}$. daily. A further patient in the $250 \mathrm{mg}$. group was given 25 units of ACTH. and one patient in the $500 \mathrm{mg}$. group was given $50 \mathrm{mg}$. cortisone. both daily.

Five patients in the $250 \mathrm{mg}$. group and four in the $500 \mathrm{mg}$. group were receiving diuretics at the time of the ampicillin assay. The diuretics were frusemide, bendrofluazide or mersalyl.

SPECIMENS FOR ASSAY All specimens were collected by the person administering the ampicillin and delivered to the laboratory within two hours of collection.

Sputum was collected during the first hour after administration of the drug and discarded. All the sputum produced between the first and second hour and between the second and third hour was collected for assay. In order to reduce as far as possible the risk of contamination of sputum specimens with saliva, patients were told to collect only material actually coughed up. At the end of each period of collection, the patient was asked to cough forcibly in order to empty the bronchial passages as far as possible.

Saliva and serum were collected two hours after administration of the drug.

The degree of purulence of the sputum was estimated by naked-eye examination in the laboratory. It was graded as follows: mucoid; less than $30 \%$ pus : 30 to $70 \%$ pus; more than $70 \%$ pus. 


\section{BACTERIOLOGICAL METHODS}

Assays A cup diffusion technique, similar to that recommended by Heathcote and Nassau (1951), was used for the ampicillin assay. A peptone yeast extract agar was melted and cooled to $50^{\circ} \mathrm{C}$. To $200 \mathrm{ml}$. agar was added $4 \mathrm{ml}$. of a 48 -hour nutrient broth culture of Sarcina lutea. After thorough mixing, $20 \mathrm{ml}$. quantities were pipetted into sterile $8.5 \mathrm{~cm}$. plastic Petri dishes. The plates were dried at $37^{\circ} \mathrm{C}$. Four cups were then cut in each plate using a metal cork borer of $8 \mathrm{~mm}$. diameter. Of the fluid under test $0.06 \mathrm{ml}$. was placed into each of two cups. The plates were incubated at $37^{\circ} \mathrm{C}$. for 48 hours.

Test Fluids Assays were carried out on neat serum and on 1 in 10 and 1 in 100 dilutions made in sterile deionized water. Sputum was homogenized by shaking mechanically with an equal volume of sterile water and four glass beads. The neat homogenate was used for the assay. The saliva was assayed without dilution.

Standard Solutions of Ampicillin The following range of ampicillin concentrations was used: $1 \cdot 0,0 \cdot 5$. $0.25,0.12$, and $0.06 \mu \mathrm{g}$. per $\mathrm{ml}$. in sterile water. Each of the standard ampicillin concentrations was also put up in duplicate. The standard solutions were included in each batch of tests.

The diameter of the zones of inhibition was measured by naked eye using dividers. A standard curve was prepared from the mean of the pairs of readings obtained for each of the standard ampicillin concentrations. From the means of the two readings for the test fluids, the ampicillin concentration was read off the standard graph, using the dilution of the test fluid giving a zone of inhibition falling within the range of those of the standard dilutions. The final concentration of the drug in the test fluid was calculated, allowing for any dilution.

\section{EFFECT ON ZONES OF INHIBITION}

Sputum Standard solutions of ampicillin were prepared over the range 1.0 to $0.06 \mu \mathrm{g} . / \mathrm{ml}$. by doubling dilutions in distilled water and in sputum which did not contain any antibiotics. The diameters of the zones of inhibition at the various concentrations with and without sputum were compared after 18 hours' incubation at $37^{\circ} \mathrm{C}$.

$\mathrm{pH}$ Standard solutions of ampicillin over the range 1.0 to $0.06 \mu \mathrm{g} . / \mathrm{ml}$. were prepared in phosphate buffer solutions at $p \mathbf{H} 6 \cdot 0,6 \cdot 6,7 \cdot 0,7 \cdot 4,7 \cdot 8$, and $8 \cdot 0$. Similar series were prepared in specimens of sputum of $p \mathrm{H}$ $6 \cdot 0,6 \cdot 5,7 \cdot 0,7 \cdot 5$, and $8 \cdot 0$. After incubation at $37^{\circ} \mathrm{C}$. for 18 hours, the diameters of the zones of inhibition were compared with those obtained with equivalent solutions in distilled water.
Penicillinase-producing Organism A series of ampi- $\vec{F}$ cillin solutions in sputum containing no other inhi- क्? biting substances were prepared in $1 \mathrm{ml}$. quantities in duplicate. To one series was added one drop of an $\underline{\bar{\sigma}}$ 18 hours nutrient broth culture of a strain of $\bar{s}$ Escherichia coli which was known to produce penicil- $\overparen{\mathbb{}}$ linase. The diameters of the zones of inhibition were compared after 18 hours' incubation at $37^{\circ} \mathrm{C}$.

\section{ROUTINE BACTERIOLOGICAL INVESTIGATIONS}

All specimens of sputum homogenates were cultured on blood agar and boiled-blood agar plates and incubated in $10 \% \mathrm{CO}_{2}$.

Ampicillin sensitivity tests were carried out using the filter paper disc method, serial dilutions in nutrient $\omega$ or boiled-blood agar, and serial dilution in broth. $\omega$ Bactericidal tests were carried out on some strains by subculturing from the broth tubes, in which growth 음 had been inhibited, on to nutrient agar plates. Sensitivity tests were done on all strains of potential $\vec{z}$ respiratory pathogens and on cultures of lactosefermenting coliforms, Proteus, and Pseudomonas pyocyanea.

\section{RESULTS}

\section{EFFECT ON ZONES OF INHIBITION}

Sputum The zones of inhibition obtained with the ampicillin solutions made up in sputum were identical with those obtained with ampicillin in $\varrho$ distilled water.

$\mathrm{p} H$ The diameters of the zones of inhibition obtained with the ampicillin solutions in phosphate buffer $p H 6.0,6.6$, and 7.0 were the same as those obtained with solutions in distilled water. At $p \mathrm{H}$ 음 $7 \cdot 4,7 \cdot 8$, and 8.0 the zones were progressively smaller. In sputum, however, the zones were similar over the $\mathrm{pH}$ range 6.0 to 8.0 and they were 3 . the same as those obtained with equivalent solutions of the drug in distilled water.

Penicillinase-producing Organism The presence of a culture of penicillinase-producing Esch. coli caused a drop of $2.5 \mathrm{~mm}$. in the diameter of the zones of inhibition at all concentrations. This was equivalent to a two-fold drop in level.

PRE-TREATMENT SPECIMENS No pre-treatment N specimens have been examined in the presento series because specimens of sputum and serum from 18 patients before the start of antibiotic $\frac{C}{\mathscr{D}}$ therapy were tested for inhibitors in a previous? series (Hafez et al., 1965) using the same assay method as was used in the present investigation. These results showed that "there was no evidence $\mathbb{D}$ of the presence in sputum of substances other than antibiotics which might cause non-specific inhibition in the cup-diffusion assay technique used'. 


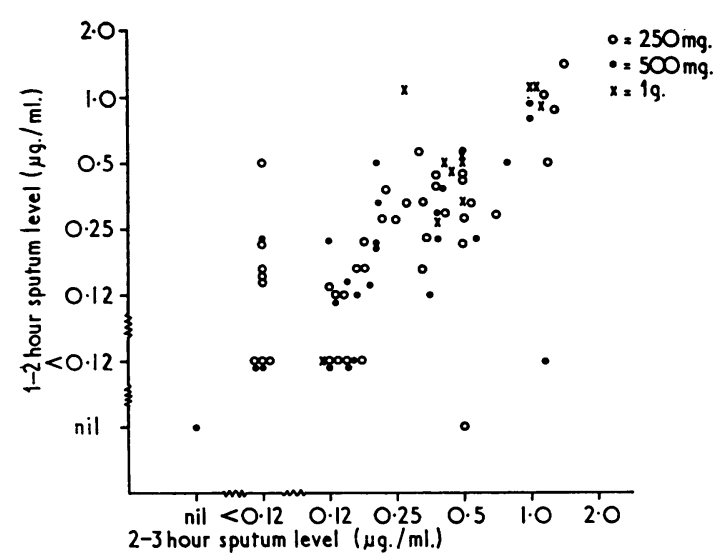

FIG. 1. Comparison of 1-2 and 2-3 hour sputum levels after $250 \mathrm{mg}$., $500 \mathrm{mg}$. or $1 \mathrm{~g}$. ampicillin.

COMPARISON OF 1-2 AND 2-3 HOUR SPUTUM LEVELS Comparison of the 1-2 and 2-3 hour sputum levels in patients receiving $250 \mathrm{mg}$., $500 \mathrm{mg}$., and $1 \mathrm{~g}$. doses of ampicillin is shown in Figure 1. The levels were similar in individual patients. The statistical analysis for all three doses is shown in the Appendix (Table A). There was a correlation of approximately 0.8 between the levels of ampicillin in the 1-2 and 2-3 hour specimens after the $250 \mathrm{mg}$. dose. The number of estimations after the $500 \mathrm{mg}$. and $1 \mathrm{~g}$. doses was too small to allow of statistical analysis as shown by very wide confidence limits, although the levels appeared to be similar in individual patients. Since there was

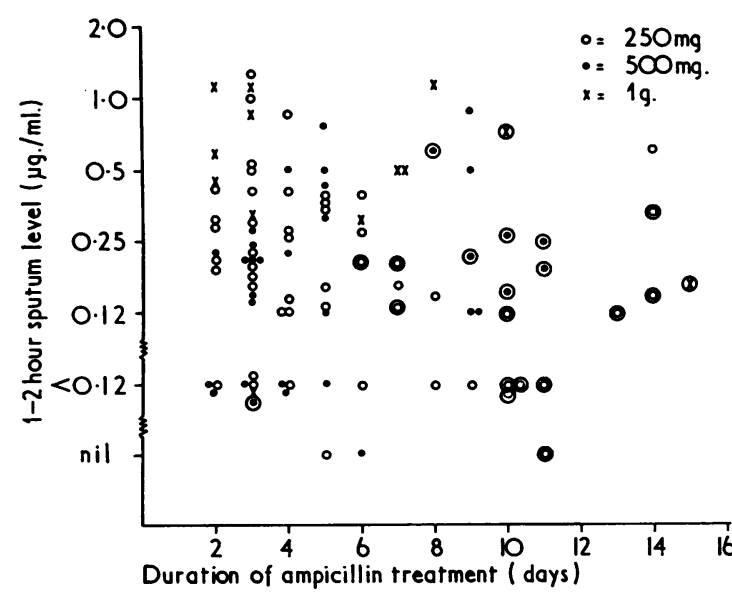

FIG. 2. Effect of duration of ampicillin treatment on 1-2 hour sputum level. Levels obtained on repeat assays are shown with an outer ring round the symbol. little difference between the 1-2 and 2-3 hour levels, only the 1-2 hour sputum level has been considered in the following analyses.

\section{EFFECT OF DURATION OF TREATMENT}

Figure 2 shows the correlation between the duration of treatment and the 1-2 hour sputum level including repeated assays on the same patient in 20 cases. There was no relationship between the duration of therapy and the ampicillin level, but the number of specimens assayed after more than 8 days' treatment was small.

\section{EFFECT OF DIFFERENT DOSES OF AMPICILLIN}

Sputum Table II shows a comparison of the 1-2 hour sputum levels after varying doses of ampicillin. There was no statistical difference in the levels after 250 and $500 \mathrm{mg}$. doses. The mean level of the 11 specimens of sputum collected after the $1 \mathrm{~g}$. dose was significantly higher than for the two lower doses.

\section{T A B L E I I}

COMPARISON OF 1-2 HOUR SPUTUM LEVELS AFTER VARYING DOSES OF AMPICILLIN

\begin{tabular}{|c|c|c|c|c|c|c|c|}
\hline \multirow{2}{*}{$\begin{array}{c}\text { Dose of } \\
\text { Ampi- } \\
\text { cillin } \\
\text { q.i.d. }\end{array}$} & \multirow{2}{*}{$\begin{array}{c}\text { Total } \\
\text { No. of } \\
\text { Patients }\end{array}$} & \multicolumn{5}{|c|}{ 1-2 hour Sputum Level ( $\mu \mathrm{g} . / \mathrm{ml})}$. & \multirow{2}{*}{$\begin{array}{c}\text { Mean } \\
\text { Level } \\
(\mu \mathrm{g} . / \mathrm{ml} .)\end{array}$} \\
\hline & & nil & $<0.12$ & $\begin{array}{c}0 \cdot 12- \\
0 \cdot 24\end{array}$ & $\begin{array}{c}0 \cdot 25- \\
0 \cdot 49\end{array}$ & $0.5+$ & \\
\hline $\begin{array}{l}250 \mathrm{mg} . \\
500 \mathrm{mg} . \\
1 \mathrm{~g} .\end{array}$ & $\begin{array}{l}40 \\
26 \\
11\end{array}$ & $\begin{array}{l}1 \\
1 \\
0\end{array}$ & $\begin{array}{l}7 \\
6 \\
1\end{array}$ & $\begin{array}{r}13 \\
11 \\
0\end{array}$ & $\begin{array}{r}13 \\
3 \\
3\end{array}$ & $\begin{array}{l}6 \\
5 \\
7\end{array}$ & $\begin{array}{l}0.30 \\
0.26 \\
0.65\end{array}$ \\
\hline
\end{tabular}

Serum Table III shows a comparison of the serum levels after three doses of ampicillin. The serum levels increased with the dose of ampicillin. The mean serum level in patients on the $1 \mathrm{~g}$. dose was significantly higher than the mean levels for the two lower doses which did not in fact differ significantly from each other.

\section{T A B L E I I I}

COMPARISON OF SERUM LEVELS AFTER VARYING DOSES OF AMPICILLIN

\begin{tabular}{|c|c|c|c|c|c|c|c|}
\hline \multirow{2}{*}{$\begin{array}{l}\text { Dose of } \\
\text { Ampi- } \\
\text { cillin } \\
\text { q.i.d. }\end{array}$} & \multirow[b]{2}{*}{$\begin{array}{c}\text { Total } \\
\text { No. of } \\
\text { Patients }\end{array}$} & \multicolumn{5}{|c|}{ Serum Level ( $\mu \mathrm{g} . / \mathrm{ml})}$. & \multirow{2}{*}{$\begin{array}{c}\text { Mean } \\
\text { Level } \\
(\mu \mathrm{g} . / \mathrm{ml} .)\end{array}$} \\
\hline & & $<2 \cdot 0$ & $\begin{array}{l}2 \cdot 0- \\
3 \cdot 9\end{array}$ & $\begin{array}{l}4 \cdot 0- \\
7 \cdot 9\end{array}$ & $\begin{array}{l}8 \cdot 0_{-} \\
15 \cdot 9\end{array}$ & $16 \cdot 0+$ & \\
\hline $\begin{array}{l}250 \mathrm{mg} . \\
500 \mathrm{mg} . \\
1 \mathrm{~g} .\end{array}$ & $\begin{array}{l}40 \\
26 \\
11\end{array}$ & $\begin{array}{l}4 \\
1 \\
0\end{array}$ & $\begin{array}{r}14 \\
6 \\
0\end{array}$ & $\begin{array}{l}9 \\
9 \\
2\end{array}$ & $\begin{array}{l}7 \\
7 \\
4\end{array}$ & $\begin{array}{l}6 \\
3 \\
5\end{array}$ & $\begin{array}{r}7 \cdot 67 \\
8 \cdot 45 \\
16 \cdot 62\end{array}$ \\
\hline
\end{tabular}

Saliva The levels of ampicillin in the saliva are shown in Table IV. There was no difference in the levels after the $250 \mathrm{mg}$. and $500 \mathrm{mg}$. doses, but when ampicillin was given in $1 \mathrm{~g}$. doses there was a significant increase over the levels after the 
smaller doses. A comparison of the sputum and saliva levels is shown in Figure 3. High saliva levels were not necessarily associated with high sputum levels.

\section{T A B L E I V}

COMPARISON OF SALIVA LEVELS AFTER VARYING DOSES OF AMPICILLIN

\begin{tabular}{|c|c|c|c|c|c|c|c|}
\hline \multirow{2}{*}{$\begin{array}{c}\text { Dose of } \\
\text { Ampi- } \\
\text { cillin } \\
\text { q.i.d. }\end{array}$} & \multirow{2}{*}{$\begin{array}{c}\text { Total } \\
\text { No. of } \\
\text { Patients }\end{array}$} & \multicolumn{5}{|c|}{ Saliva Level $(\mu \mathrm{g} . / \mathrm{ml})}$. & \multirow[b]{2}{*}{$\begin{array}{c}\text { Mean } \\
\text { Level } \\
(\mu \mathrm{g} . / \mathrm{ml} .)\end{array}$} \\
\hline & & Nil & $<0.06$ & $\begin{array}{c}0.06 \\
0.24\end{array}$ & $\begin{array}{c}0.25 \\
0.49\end{array}$ & $0.5+$ & \\
\hline $\begin{array}{l}250 \mathrm{mg} . \\
500 \mathrm{mg} . \\
1 \mathrm{~g} .\end{array}$ & $\begin{array}{l}44 \\
28 \\
17\end{array}$ & $\begin{array}{l}9 \\
2 \\
0\end{array}$ & $\begin{array}{r}23 \\
19 \\
2\end{array}$ & $\begin{array}{l}8 \\
5 \\
7\end{array}$ & $\begin{array}{l}2 \\
1 \\
5\end{array}$ & $\begin{array}{l}2 \\
1 \\
3\end{array}$ & $\begin{array}{l}0.10 \\
0.11 \\
0.28\end{array}$ \\
\hline
\end{tabular}

1The number of patients included 4 in the $250 \mathrm{mg}$. group, 2 in the $500 \mathrm{mg}$. group, and 6 in the $1 \mathrm{~g}$. group who were excluded from th main analysis because the saliva levels were the same as or higher than the sputum levels.

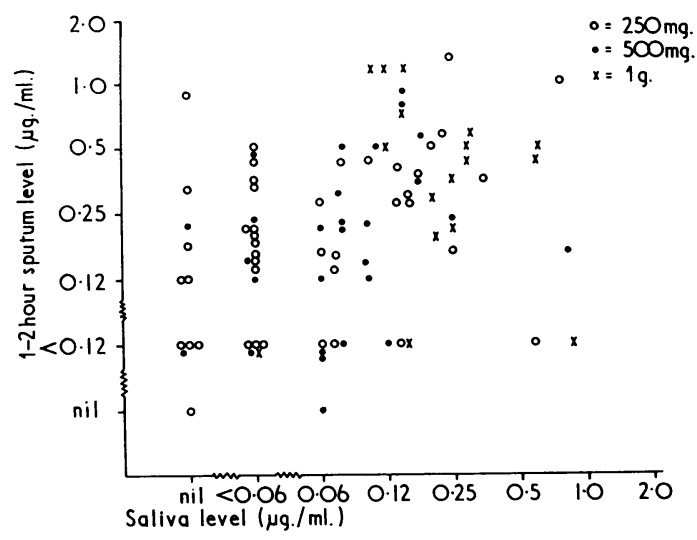

FIG. 3. Comparison of 1-2 hour sputum and saliva levels after $250 \mathrm{mg}$., $500 \mathrm{mg}$. and $1 \mathrm{~g}$. ampicillin.

Comparison of Sputum and Serum Levels The relationship between the 1-2 hour sputum and serum levels is shown in Figure 4. The sputum levels were on the whole 30 to 40 times lower than the serum levels, but for any given serum level there was a considerable scatter in the sputum levels. There is apparently no close correlation between the 1-2 hour sputum level and the corresponding serum level (see Appendix, Table B).

EFFECT OF CORTICOSTEROIDS ON AMPICILLIN SPUTUM LEVELS The number of patients receiving corticosteroids was small, but the overall impression was that corticosteroids did not affect the 12 hour sputum level at any of the three doses of ampicillin studied.

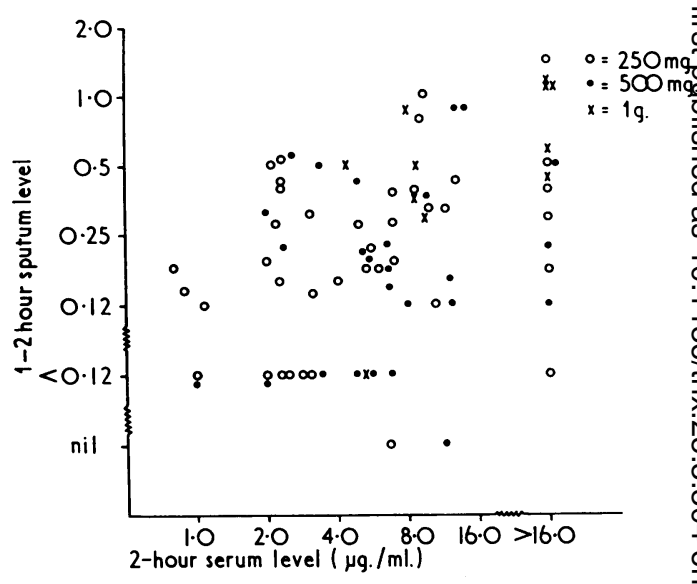

FIG. 4. Comparison of 1-2 hour sputum level and $z$ hour serum level after $250 \mathrm{mg}$., $500 \mathrm{mg}$. and $1 \mathrm{~g}$. ampicillin

EFFECT OF DIURETICS ON AMPICILLIN SPUTU LEVELS The number of patients treated with diuretics was small, but there was no suggestiog that diuretics had any effect on the 1-2 hou sputum levels of ampicillin.

RELATION BETWEEN DEGREE OF PURULENCE AN SPUTUM LEVEL The mean 1-2 hour ampicilli sputum levels related to the degree of purulence of the sputum are shown in Table V. There w娄 no significant correlation between the mean sputum level and the degree of purulence after either the $250 \mathrm{mg}$. or $500 \mathrm{mg}$. dose. In the 1 d specimens from patients receiving $1 \mathrm{~g}$. ampicilli four times daily, there was a statistically sign?. ficant increase in sputum level with increase if purulence.

T A B LE V

MEAN SPUTUM LEVELS OF AMPICILLIN RELATED T‡ MEAN SPUTUM LEVELS OF AMPICILLIN RELATED T⿱宀
DEGREE OF PURULENCE OF SPUTUM

\begin{tabular}{|c|c|c|c|c|}
\hline \multirow{2}{*}{$\begin{array}{c}\text { Dose of } \\
\text { Ampicillin } \\
\text { q.i.d. }\end{array}$} & \multicolumn{3}{|c|}{$\begin{array}{c}\text { Mean 1-2 hour Sputum Level } \\
(\mu \mathrm{g} . / \mathrm{ml} .)\end{array}$} & \multirow{2}{*}{$\begin{array}{l}\text { Total No. } \\
\text { of Speciment }\end{array}$} \\
\hline & $<30 \%$ Pus & $\begin{array}{l}30 \text { to } 70 \% \\
\text { Pus }\end{array}$ & $\begin{array}{l}\text { More than } \\
70 \% \text { Pus }\end{array}$ & \\
\hline $\begin{array}{l}250 \mathrm{mg} . \\
500 \mathrm{mg} . \\
1 \mathrm{~g} .\end{array}$ & $\begin{array}{l}0.20 \\
0.34 \\
0.36\end{array}$ & $\begin{array}{l}0.27 \\
0.26 \\
0.56\end{array}$ & $\begin{array}{l}0.38 \\
0 \cdot 19 \\
0.95\end{array}$ & $\begin{array}{l}40 \\
26 \\
11\end{array}$ \\
\hline
\end{tabular}

RELATION BETWEEN WEIGHT OF PATIENT AN SPUTUM LEVEL There was no evidence that the weight of the patient influenced the 1-2 houf sputum level. 
REPEATED ASSAYS Table VI shows the 1-2 hour sputum levels in 20 patients in whom assays were repeated after the same or higher doses on different occasions. There was some variation between the assays on the same dose, the tendency being for the repeat assay to be lower than the first reading. In the few patients tested after different doses, the level increased with the dose.

T A B L E V I

REPEATED ASSAYS ON 1-2 HOUR SPUTUM SPECIMENS FROM THE SAME PATIENT ON THE SAME OR A HIGHER DOSE

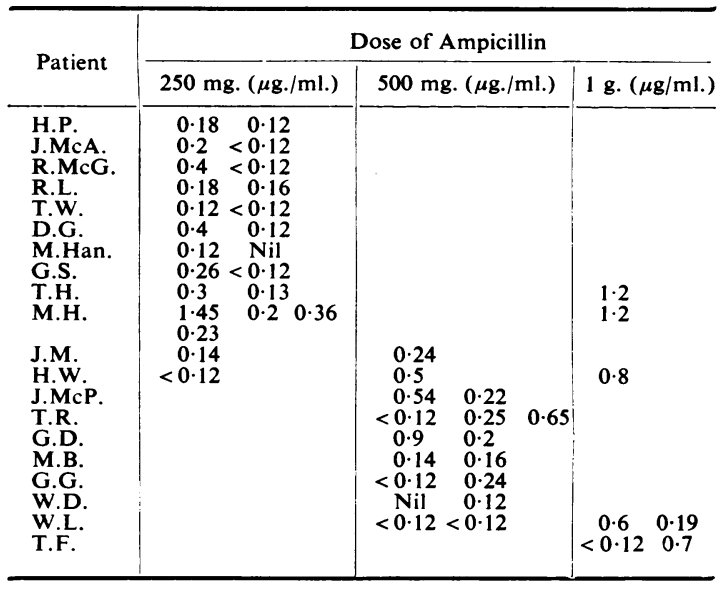

ISOLATION OF BACTERIA FROM SPUTUM AND THEIR SENSITIVITY TO AMPICILLIN Streptococcus pneumoniae was isolated from eight specimens of sputum examined before the start of ampicillin treatment, Haemophilus influenzae from five, and Strep. pneumoniae and $H$. influenzae from one. No pathogens were isolated from 55 pre-treatment specimens but many patients had received some antibiotic treatment before the collection of the sputum. No pre-treatment specimens were examined from eight patients.

From the specimens on which assays were carried out (i.e., after the start of ampicillin treatment) Table VII shows the bacteria isolated:

T A B L E V I I

\begin{tabular}{|c|c|c|c|c|c|}
\hline \multirow{2}{*}{\multicolumn{3}{|c|}{ Organism Isolated }} & \multicolumn{3}{|c|}{ Ampicillin } \\
\hline & & & \multirow{2}{*}{$\begin{array}{c}250 \mathrm{mg} . \\
5 \\
1 \\
1 \\
6 \\
3 \\
0\end{array}$} & \multirow{2}{*}{$\begin{array}{c}500 \mathrm{mg} . \\
1 \\
2 \\
1 \\
6 \\
2 \\
4\end{array}$} & \multirow{2}{*}{$\begin{array}{c}1 \text { g. } \\
0 \\
1 \\
0 \\
2 \\
2 \\
2\end{array}$} \\
\hline $\begin{array}{l}\text { Staph. pyogenes } \\
\text { Kl.pneumoniae } \\
\text { Non-haemolytic stre } \\
\text { Lactose-fermenting } \\
\text { Proteus sp. .. } \\
\text { Ps. pyocyanea }\end{array}$ & $\begin{array}{l}\ldots \\
\cdots \\
\text { eptococcus } \\
\text { coliform } \\
\ldots \\
\ldots\end{array}$ & $\begin{array}{l}\cdots \\
\cdots \\
\cdots \\
\cdots\end{array}$ & & & \\
\hline
\end{tabular}

All strains from specimens taken after the start of treatment were resistant, by all methods tested, to concentrations of ampicillin well above those found in the sputum, with the exception of two strains of Klebsiella pneumoniae ; one strain was sensitive in agar but resistant in broth, the other failed to grow on subculture and therefore sensitivity tests could not be carried out.

\section{DISCUSSION}

The estimation of antibiotics in body fluids has been widely employed as a guide to the optimum dosage of the drug to be given: such reports have usually been based on serum levels. The results of previous work with penicillin (Hafez et al., 1955) and with ampicillin (May and Delves, 1965) suggest that sputum levels are appreciably lower than the corresponding serum levels and therefore serum levels may not be a satisfactory indication of the tissue levels in the lungs or in the walls of the bronchi. The current investigation was carried out to determine the sputum levels obtained after the administration of oral ampicillin in patients with respiratory disease during courses of $250 \mathrm{mg}$., $500 \mathrm{mg}$., or $1 \mathrm{~g}$. 6-hourly. Serum and saliva were also assayed in parallel with the sputum.

The most striking finding in the present investigation was the difference in ampicillin sputum levels between patients on the same dose of drug. For example, with a dose of $250 \mathrm{mg}$. ampicillin, sputum levels varied from nil (in two patients) to $1.45 \mu \mathrm{g} . / \mathrm{ml}$. This is an even greater range than in the series reported by May and Delves (1965) in which it was nil to $0.6 \mu \mathrm{g}$. $/ \mathrm{ml}$. in 24-hour collections of sputum from patients receiving $1 \mathrm{~g}$. ampicillin 6-hourly. One of the possible causes of such a variation may be experimental error in the assay system used. Against this is the comparatively close correlation of the 1-2 hour and 2-3 hour sputum levels found in our patients. Also, when ampicillin solutions of known concentrations were made up in sputum or serum, and assayed by the standard method, the assay level and the known levels were very similar.

A second cause of the variation between levels in sputum from different patients, and one difficult to control, is the contamination of sputum with saliva during the collection of the sputum specimen. If the saliva contains appreciable amounts of the drug, a mixture of sputum and saliva might give a falsely high sputum level; this source of error has been avoided in the present investigation by carrying out assays on saliva in all cases and by excluding from the analysis all patients in 
whom the saliva level was the same as or greater than the sputum level. If the saliva contains little or no antibiotic, as was frequently the case in the current series, contamination of the sputum with saliva would give a low reading for the sputum. An attempt was made to prevent this contamination by asking the patients to collect only material actually coughed up, but it cannot be guaranteed that saliva contamination did not occur. However, the correlation between the 1-2 hour and 2-3 hour readings suggests that the effect may not be great. Nevertheless the sputum levels must be considered as minimal readings and salival contamination may account for some of the variation. This is a variation inherent in the method and one that applies equally to all investigations of drug sputum levels, unless bronchoscopy specimens are used.

It seemed possible that $p \mathrm{H}$ or substances in the sputum might contribute to the variable results. However, assays of known concentrations of ampicillin in specimens of sputum of varying $p \mathrm{H}$ did not demonstrate any difference in readings over the $p \mathrm{H}$ range $6 \cdot 0$ to $8 \cdot 0$. Similarly, assays of solutions with and without the addition of sputum containing no other antibiotics showed no difference in the readings. Therefore it seems unlikely that sputum $\mathrm{pH}$ or factors in 'normal' sputum contributed to the variations.

Maddocks and May (1969) have suggested that the presence of penicillinase-producing organisms in the sputum may reduce the active level of penicillinase-sensitive antibiotics. They found that in five out of six patients with chronic bronchial disease excreting penicillinase-producing organisms in their sputum only a trace of ampicillin was detectable in the sputum and that ampicillin added to the sputum was completely inactivated in all cases. This inactivation was prevented in five of the six cases by the addition of cloxacillin to the sputum; in the sixth, partial inactivation occurred and the patient did not respond clinically to the combined therapy. In one patient there was a sputum level of $0.6 \mu \mathrm{g} . / \mathrm{ml}$. in spite of the fact that the sputum inactivated the ampicillin in vitro. In a previous report (Hafez et al., 1965) on penicillin levels in sputum, the levels attained in patients excreting penicillinase-producing organisms in the sputum were compared with those not excreting such organisms. There was no difference in the levels in the two groups. These tests were therefore not carried out in the present investigation. However, mixtures of varying ampicillin concentrations in sputum with and without the addition of a broth culture of a penicillinase-producing strain of Esch. coli were assayed ; there was a tw $\overrightarrow{\bar{\partial}-}$ fold drop in level in the presence of the Esch. cabi culture, but in none of the concentrations from 1.0 to $0.06 \mu \mathrm{g} . / \mathrm{ml}$. was the ampicillin activi completely neutralized. It seems therefore thळt while the presence of a penicillinase-producing organism may cause a decrease in ampicillin levê this may not be much and is unlikely to accoußr for the wide variations found. Maddocks and May's results suggest that any reduction in levê that occurs may be of clinical significance an therefore it is the reduced level, as detectable the present series, that should be used in assessing the optimal dosage of ampicillin.

There will also be variation due to differin absorption rates between individuals. This shout be reflected in the serum levels, which also showed big variations in the present investigation: ho ever, low sputum levels were not necessarily ass ciated with low serum levels.

Early reports showed that after a single dose the serum level rose in direct proportion to the increase in dose from $250 \mathrm{mg}$. to $1 \mathrm{~g}$. (Knudseo, Rolinson, and Stevens, 1961). May and Delve (1964) found that in sputum from small groups of patients the mean level was $0.08 \mu \mathrm{g} . / \mathrm{ml}$. six houg after a dose of $250 \mathrm{mg}$. and $0.24 \mu \mathrm{g} . / \mathrm{ml}$. six houß after $500 \mathrm{mg}$. A graph showing repeated estim $\overrightarrow{\vec{F}}$ tions on two patients, one receiving $250 \mathrm{mg}$. and the other $500 \mathrm{mg}$., showed that, while difference occurred, these were not consistent and that the third to fourth day of treatment the leve were similar on the two doses. In a later pape (May and Delves, 1965), the mean 24-hour sputum level of 20 patients receiving $1 \mathrm{~g}$. six-hourly wh $0.25 \mu \mathrm{g}$. $/ \mathrm{ml}$. In our series there was no difference between the sputum levels after $250 \mathrm{mg}$. or 500 $\mathrm{mg}$. doses, but the levels were statistically higher after $1 \mathrm{~g}$.

Most of these estimations were carried out after three or more days of treatment, though the was no evidence that the duration of therapes affected the sputum level. The serum levels in creased with increasing dose, though the differ ence between the specimens collected after the $250 \mathrm{mg}$. and $500 \mathrm{mg}$. doses was much less marked than between the $500 \mathrm{mg}$. and $1 \mathrm{~g}$. doses. The saliva levels were similar after the $250 \mathrm{mg}$. an $500 \mathrm{mg}$. doses but higher after the $1 \mathrm{~g}$. dose.

The most common way of judging if adequate doses of an antibiotic are being given is to est mate the serum level and to compare this with the minimum inhibitory concentrations for the common pathogens. However, the serum leve्य may not represent the tissue level. There may be 
a gradient between the blood vessels and the bronchial wall (Crofton, 1969). In chronic bronchitis the site of infection is on or just below the surface of the bronchi (Hers and Mulder, 1953). If sputum levels are considered as a reflection of the lung tissue level, it is apparent from this investigation and from May and Delves' results (1965) that the levels at the site of infection may be much lower than those in the serum. The serum levels obtained after all doses in the present series should be adequate to inhibit the growth of Strep. pneumoniae and $H$. influenzae, since the minimum inhibitory concentrations of those pathogens are generally given as 0.06 and 0.25 $\mu \mathrm{g} . / \mathrm{ml}$. respectively, although some strains of $H$. influenzae are resistant to $1.0 \mu \mathrm{g} . / \mathrm{ml}$. or above (personal experience). However, sputum ampicillin levels of $0.25 \mu \mathrm{g} . / \mathrm{ml}$. or above were obtained in only 19 of 40 patients receiving $250 \mathrm{mg}$. ampicillin per dose and in 8 of 26 on $500 \mathrm{mg}$. All but one of the 11 patients receiving $1 \mathrm{~g}$. ampicillin had a sputum level of $0.25 \mu \mathrm{g} . / \mathrm{ml}$. and seven of those were of $0.5 \mu \mathrm{g} . / \mathrm{ml}$. or above. It is the sputum levels rather than the serum levels that are compatible with May and Delves' (1965), admittedly uncontrolled, clinical findings in chronic bronchitis that the $1 \mathrm{~g}$. dose is more efficient than lower doses. Further, in the present investigation all organisms isolated at the time of the assay had minimum inhibitory concentrations above the sputum levels but not always above the serum levels, suggesting that the concentration in the serum was probably not attained at the site of the organism concerned. However, no strains of $\boldsymbol{H}$. influenzae or Strep. pneumoniae were isolated, suggesting that these organisms had been eliminated.

The results of the present series confirm that ampicillin is present in the sputum in appreciable amounts after oral administration and that higher levels are obtained after a dose of $1 \mathrm{~g}$. than after $250 \mathrm{mg}$. or $500 \mathrm{mg}$. The serum levels were appreciably higher than the sputum levels. Whether the serum or sputum levels are of greater clinical significance in assessing adequacy of drug dosage could be ascertained only by careful correlation with the clinical results.

The authors wish to thank Professor J. W. Crofton and Professor B. P. Marmion for their advice. The patients investigated were under the care of Professor Crofton, Dr. A. C. Douglas, and Dr. G. J. R. McHardy. The authors also thank Miss E. Mercer, Miss M. Davidson, and Mrs. K. Pratt for technical assistance, Mrs. J. Herson. of the Computer and
Statistics Section, Usher Institute for computational assistance, and Miss M. White for secretarial assistance. Dr. Margaret A. Calder carried out the pretreatment bacteriological examinations.

The research was supported by grants from the Scottish Hospital Endowments Research Trust, the Wellcome Foundation, the Medical Research Council, and the Chest and Heart Association.

\section{REFERENCES}

Crofton, J. (1969). Some principles in the chemotherapy of bacterial infections. Brit. med. J., 2, 209.

Hafez, F. F., Stewart, Sheila M., and Burnet, M. Eileen (1965). Penicillin levels in sputum. Thorax, 20, 219.

Heathcote, A. G. S., and Nassau, E. (1951). Concentrations of penicillin in the lungs. Lancet, $1,1255$.

Hers, J. F. P., and Mulder, J. (1953). The mucosal epithelium of the respiratory tract in mucopurulent bronchitis caused by Haemophilus influenzae. J. Path. Bact., 66, 103.

Höffler, D., Stegemann, I., and Scheler, F. (1966). Ampicillin levels in the serum and urine of patients with impaired renal function. Germ. med. Mth., 11, 138.

Knudsen, E. T., Rolinson, G. N., and Stevens, Shirley (1961). Absorption and excretion of "penbritin". Brit. med. J., 2, 198.

Maddocks, J. L., and May, J. Robert (1969). "Indirect pathogenicity" of penicillinase-producing enterobacteria in chronic bronchial infections. Lancet, 1, 793.

May, J. Robert, and Delves, Doreen M. (1964). Ampicillin in the treatment of Haemophilus influenzae infections of the respiratory tract. Thorax, 19, 298.

(1965). Treatment of chronic bronchitis with ampicillin. Lancet, 1, 929.

A P P E NDIX TABLE A

COMPARISON OF 1-2 AND 2-3 HOUR SPUTUM LEVELS

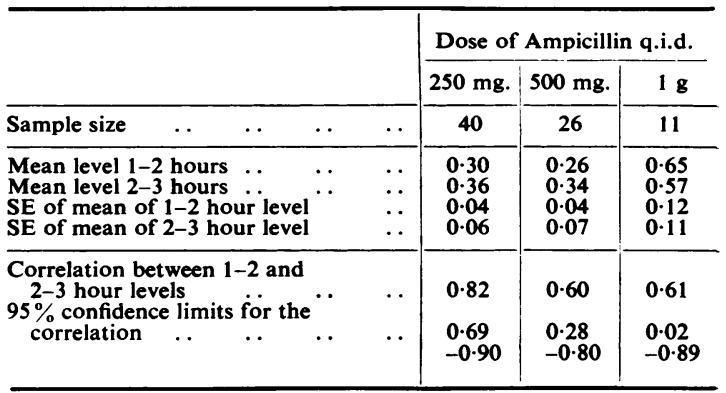

APPENDIX TABLE B

COMPARISON OF 1-2 HOUR SPUTUM LEVEL AND SERUM LEVEL AFTER 250 MG., 500 MG., AND 1 G. DOSES OF

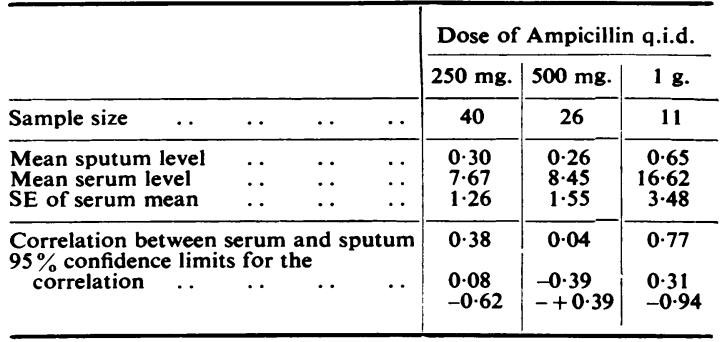

